\title{
THE NONVERBAL COMMUNICATION AND ITS INFLUENCE ON CUSTOMER PERCEPTIONS TOWARDS SERVICE ENCOUNTER: AN EMPIRICAL STUDY IN THE IRAQI BANKING SERVICE
}

\author{
Raafat Awad Mosa ${ }^{\mathrm{i}}$ \\ University of Basrah, \\ College of Admin \& Economics, \\ Department of Business Admin,
} Iraq

\begin{abstract}
:
In the midst of a business environment that gave the customer an advanced position in the interests and orientations of marketing organizations, the method of nonverbal communication comes to occupy an important and integrated space with verbal or word communication in the field of interaction with customers in order to achieve the best response to them and build the image and positive view towards service organizations. Therefore, the current study sought to measure the influence of nonverbal communication behaviors and signals practiced by frontline employees in service organizations on the perceptions of customers during the encounter that happens between the two parties. The banking sector was chosen as a domain of study, and the quantitative approach and the random sampling method were adopted through the participation of 397 customers who received different services from banks operating in Basra Governorate - Iraq. The results indicated that the behaviors and cues related to nonverbal communication used by the frontline employees of the respective banks positively affect the perceptions of the customers surveyed, and among the silent cues in this form of communication, body language had the strongest influence on customer perception in service encounters. The study recommended that banks should strive to create a friendly climate in providing service in which work is based on the principle of customer friendship, where nonverbal communication is integrated with verbal.
\end{abstract}

Keywords: nonverbal communication, body language, paralanguage, physical appearance, customer perceptions

'Correspondence: email raafat.musa@uobasrah.edu.iq 


\section{Introduction}

With the expansion of global interest in the service industry, the adage "actions speak louder than words" has become relevant to the language of communication and understanding with customers in service marketing (Bailey, 2018). The Service is known in its production and delivery by interactive nature between the service provider and customers, where the method of communication used in the encounters that occur between front line employees and customers plays a vital role in shaping the experience and perceptions of those customers (Ulusoy, 2015). Factually, the method of communication used either contributes to the creation of a passable road between the two parties or on the contrary, generates a storm that raises negative perceptions towards the services and the organization as a whole (Vo, 2016), this method is considered as "the beating heart of the relationship with customers". More precisely, the intimate contact and interaction between frontline employees and customers are the critical foundation for building the best service scenario and superior service organizations (O'Hair et al, 2008; Weng et al., 2016). A successful service organization is one that devotes great attention to uniting its efforts in order to be consistent in responding to customer expectations and don't disappoint them (Sarpong, 2016). Undoubtedly, that a service organization whose work involves high levels of interaction with customers' needs to develop nonverbal communications in order to paint a positive image of its services in the minds of those customers (Irabatti, 2012). Honestly, measuring customer perceptions is an indispensable step in formulating the marketing strategy of any organization seeking to develop and deliver premium services (Raji \& Zainal, 2016). Thus, studying and understanding customers' perceptions will inevitably reflect on the ability to positively influence those perceptions and build long-term relationships with them (Lake, 2009).

Today, in light of the intense competition within the business environment, the customer occupies an advanced position in the concerns of service organizations, and this stems from the belief that customer happiness will contribute to attracting new customers (Danish et al, 2018). In contrast, many organizations including banks strive to win customer loyalty (Carallon \& Modina, 2013). Given the vital role played by communication in achieving strong interdependence between customers and service providers, banking competitive efforts often revolve around building customer perceptions that increase market share and profits by improving the ways of communication and interaction with customers (Piric et al., 2018) (Webster \& Sundaram, 2009). The method of communication determines how the customer interprets the messages sent from the bank's frontline employees and And the image that he will create in his mind about the providing services (Alakwe \& Okpara, 2017). In fact, the interaction between the customer and the frontline employees is not limited to verbal communication, as the customer sees the employees, not only hears them $(\mathrm{Wu}, 2018)$. The customer's perceptions can be formed during the service encounter through his evaluation of the employees' appearance, tone of voice, eye glances, and body language they display (Lee \& Park, 2018). Evidence in the scope of marketing asserts that nonverbal 
behaviors or cues are a critical component of the communication and interaction puzzle between customers and frontline employees (Chapman, 2018), It is the other form of communication that helps to transmit a lot of information in the field of human communication (Cho, 2012). Frequently, nonverbal communication is seen as the most accurate tool in communicating desired meaning compared to spoken words, as a smile can convey many meanings that words cannot express (Mojizinovic, 2011).

Since the success of the service industry depends primarily on interpersonal interactions, nonverbal communication is a critical factor in customers' evaluation of service (Gabbott \& Gillian, 2000). Nonverbal behaviors in services are just as important as verbal behaviors in determining the strength of the relationship between the customer and the service staff (Cho, 2012). Therefore, developing these employees' abilities in nonverbal communication is an important requirement for customer service and generating a positive outlook about service encounters (Irabatti, 2012). Despite the importance of the topic of nonverbal communication in marketing, there have been a limited number of attempts to study the influence of this type of communication on customer perceptions (Webster \& Sundaram, 2009). Although there are many studies that have discussed nonverbal communication, which confirmed the strong influence of such communication on participants' perceptions of a specific situation or event. However, that researchers in management science have lagged behind in understanding nonverbal communication, the research interests are still scattered across other practical areas of psychology and anthropology, and there is a clear need for a comprehensive review of those behaviors and cues in marketing (Bonaccio et al, 2016). More specifically, in the scope of service marketing, in order to improve their services, service organizations must focus on improving the ways their employees communicate and interact with customers, as well as understanding the nature of customers' perceptions of the services they provide (Hoang, 2011) (Mmutle \& Shonhe, 2017).

\subsection{Objectives of the study}

Based on the discussions and evidence revealed by the previous literature review, it is inferred that the ability of banks to develop and provide differentiated services is closely related to the understanding of customer perceptions towards the service encounter. Today, banks are operating in light of a marketing environment characterized by intense competition, which imposes the necessity of having an accurate understanding of customers' requirements in order to make them happy and enhance their sense of satisfaction. Certainly, the response that lives up to or exceeds the expectations of customers will not be achieved without making real attempts to measure customer perceptions and identify the factors affecting those perceptions. the attempts to know customer perceptions will serve as a compass that helps banks determine the effectiveness of their marketing orientations to serve the customer. Due to the interactive nature in the process of producing and providing services, the communication method used by frontline employees emerges as a decisive factor in drawing the image that the customer perceives and preserves in his memory Towards service encounters and 
interactions. In many cases, a number of studies go further to describe nonverbal communication as being more expressive in conveying the message and meaning to clients than spoken words. Therefore, this study sought to diagnose the nature of customers' perceptions towards the service encounters in banks operating within the administrative borders of Basra Governorate - Iraq, and then measure the influence that nonverbal communication behaviours or signals that are issued by frontline employees in the concerned banks can achieve on those perceptions.

\subsection{Study Questions}

The study attempts to answer the following questions:

Q1: To what extent do the frontline employees in the Iraqi banks under study practice nonverbal communication behaviors with customers during the service encounter?

Q2: How does the use of nonverbal communication behaviours by frontline employees affect customers' perceptions of the service provision process in the Iraqi banks under study?

The importance of this study was manifested in its dealing with the variables that confirmed the contributions and results of a number of previous studies on their importance in drawing the future relationship with the client. In addition to choosing a field that reflects the true face of the development of countries and the progress of their people in measuring the strength of the correlation and influence between the studied variables, which is the banking sector.

\section{Literature Review}

\subsection{Nonverbal Communication}

\subsubsection{The Concept of Nonverbal Communication}

The communication that humans use on a daily basis from greeting, shaking hands, and talking to others is a continuous process of exchanging messages that include information, thoughts, feelings, life experiences, and knowledge gained from situations and events experienced by a person (Negi, 2009). The term "communication" means "to share" or "transmit" messages that carry different meanings between people with the main goal of understanding others (Abdullah et al, 2020). When we communicate with each other, We use communication through different tools and means that are categorized into two forms: verbal and nonverbal communication (Hacioglu et al, 2008), The first represents the most obvious form of communication that occurs between people (Abushihab, 2012), and it refers to the use of words and the language of oral speech in conveying messages and expressing views (Abdullah et al, 2020). The second form of communication is called nonverbal communication, and it expresses the language of understanding and rapprochement between communicators through symbols, signs, and means that are outside the framework of spoken words such as facial expressions and gestures (Denault et al, 2020). In a more precise sense, nonverbal communications are 
those communications that take place without words (Blahova, 2015), and it is also known as silent language or sign language that governs many interactions in our lives (Plumb, 2013). Nonverbal communication is the innate aspect of communication between people through the behaviors that take place while others are present, whether consciously or unconsciously (Chapman, 2018).

It is worth noting that nonverbal communication describes every behavior that can occur contrary to what is said (Bose, 2019). On this point, research results show that gestures, facial expressions, tone of voice, and eye signals can transmit (93\%) of feelings and sensations between communicators, while $(7 \%)$ come from what we say in a verbal or actual form (Hacioglu et al., 2008), This denotes that nonverbal communication takes a wide space in the style of communication between humans, as it complements and emphasizes verbal communication (Lee \& Park, 2018). In this regard, Abercrombie, (1968) pointed out that "we humans talk with our vocal cords, but we communicate with our facial expressions, our tone of voice and our entire body". generally, there are a number of characteristics that characterize nonverbal communication, which give a strong motivation to use such communication in our daily lives. These characteristics can be listed as follows:

- Nonverbal communication expresses more clearly the complex messages that words are not enough to express, such as explaining a particular shape or describing a character (Eunson, 2012).

- Nonverbal communication is realistic and accurate at higher levels than verbal communication. In reality, the degree of control over nonverbal cues and behavior is lower than that of verbal communication, Deception or falsification is easy through the language of verbal communication by embellishing or distorting words, but this is difficult or needs time in the field of nonverbal communication that is expressed by actions (Cho, 2012). In another context, nonverbal communication is described as ambiguous in certain cases, and a single nonverbal cue may convey many meanings, for example, a person's look at their wristwatch or coughing may be met with different assessments and interpretations by others (Verderer et al, 2009; Gamble, 2019).

- In certain circumstances and situations, a person may be restricted in expressing his inner feelings using words as a result of shyness. Here, nonverbal signals are an appropriate tool to describe those feelings or situations (Bicki, 2008).

- Nonverbal communication provides multiple channels through which messages and signals can be transmitted to others such as eye gaze, facial expressions, etc., while spoken words are the only outlet for transmitting verbal messages (Fifield, 2015).

- Nonverbal cues are the main outlet that can convey (93\%) of our feelings, and similarly, we judge the feelings of others by their nonverbal behaviors (Verderer et al, 2009). 


\subsubsection{Forms of Nonverbal Communication}

Nonverbal communication takes forms or paths (Body Language, Paralanguage, Physical Appearance) in order to convey messages and create understanding with others, these forms can be summarized as follows:

\section{A. Body Language}

Body language in nonverbal communication refers to the cues that can be perceived through facial expressions, eye glances, and gestures made by others during interactions (Kyungae et al, 2011). Facial expressions constitute the richest channel in nonverbal communication that gives a clear perception of a person's mood and the state in which he expresses or restricts his feelings and what is inside him to others (Heide, 2013; Barreto, 2017). When researching anatomy, we find that there are twenty muscles in the face that allow a person to express his feelings differently such as happiness, grief, fear, anger, surprise, dissatisfaction, or disgust (Danner \& Durrschmid, 2018). In this context, field evidence reveals that (55\%) of the feelings and dimensions of the human personality can be extrapolated through the face (Hammed et al, 2020). The face is like a mirror that reflects the human spirit and emotional feelings. When a person is born, he releases the first expression in his life, which is crying (Irabatti, 2012). In addition to expressions, the face includes an important medium in the field of nonverbal cues or communication, the eye, in which eye glances such as staring and winking provide indications of hostility and interest (Bujalkova \& Zrnikova, 2016). Not to mention that eye cues help enhance understanding of other people's situations and even the ability to read their thoughts (Allan \& Pease, 2004). Here, studies confirm that when people talk to each other, they make eye contact for about (40\%) of the encounter time (Verderer et al, 2009). Body language does not stop at facial expressions and eye glances only, but extends to include gestures such as bending to express respect, waving hands, or pointing fingers for digital indications, all these movements are important signals in expressing what we want to say without words (Bicki, 2008; Eunson, 2012)

\section{B. Paralanguage}

From among foundations or principles on which the communication process is based is "It is not what we say - but how we say it." (Bailey, 2018). The term paralanguage describes the method we talk to others, such as volume or tone of the voice, manner, and speed of speech (Mijung \& Yoonji, 2010). The language or secondary dialect that we speak is a vital form of nonverbal communication and has an important role in attracting and persuading others, as the way we speak can convey the meaning clearly to the recipient or vice versa (Yeon \& Ryong, 2011). Paralanguage can give different interpretations to the person with whom we can talk, a person may speak in a low voice in order not to attract the attention of those around him, and in other cases, we find someone talking loudly to express their level of anger, annoyance, or impatience towards a certain thing (Blahova, 2015). 


\section{Physical Appearance}

Another important part of nonverbal communication is physical appearance, which simply refers to elegance in clothing and physical attractiveness (Kyungae et al, 2011). Clothes not only reflect a person's appearance, but also his inner world (Tijana et al, 2014). In many situations, it is noticed that people make their judgments on others based on their physical appearance. In this aspect, there are many research findings that support the fact that clothes and things that adorn human bodies have great influences in giving first impressions to others when they meet or interact with them (Lower, 2018). It cannot be denied fact that we live in a world in which physical appearance has become a basis for distinguishing between people and building perceptions towards their level of intelligence, the social class from which they come, the nature of the profession or job position they occupy.... etc. on this point, the results of a number of studies showed that even the category of children tends to choose friends with an attractive appearance (Wang, 2009).

\subsection{Customer Perceptions}

\subsubsection{The Concept of Customer Perceptions}

Customer perceptions are among the marketing concepts that have long been on the top of the concerns of researchers and writers, due these perceptions are closely related to the efforts of business organizations aimed at enhancing customer satisfaction (Konya et al, 2014). In general, the term perceptions express the sensations or signals received by the brain through the human senses that enable us to understand the things around us (Hoyer et al, 2012; Boamah et al, 2020). Within the scope of marketing, the concept of customer perceptions describes the nature of a customer's thinking and negative or positive feelings or experiences about a particular product or brand (Zin, 2019). In the area of service marketing, customer perceptions are of great importance in the marketing orientations of service organizations, and specifically in the area of banking service, which has recently undergone a number of changes (Piric et al, 2018). Because of the competition and technological developments that have raised the ceiling of customers' requirements for the best services, competition has provided them with wide options and alternatives ( $\mathrm{Xu}$ et al, 2007). Indeed, customer perceptions are shaped by service encounters that occur with the frontline employees, these encounters and the level of interaction between the two parties play a very important role in shaping those customers' perceptions of the service production and delivery process (Huang, 2011). The process of forming perceptions begins when the customer in the service encounter is exposed to a specific stimulus or motives, to later shift to the cognitive organization of his thoughts about what he has been exposed to from the stimulus, then the brain moves to the stage of interpreting the information or knowledge gained, building perceptions and responding (Lake, 2009; Yee \& Yazdanifard, 2014) 


\subsubsection{Dimensions of Customer Perceptions}

Customer perceptions in the scope of service are framed by two main dimensions (service consistency, service value), these two dimensions can be summarized as follows:

\section{A. Service Consistency}

Service consistency refers to the customer's expectations of obtaining the same level of service every time he interacts and communicates with the organization (Sheahan, 2018). Mostly, the concept of consistency focuses on the mechanisms of work in service organizations that should adopt homogeneous levels with regard to the process of production and service delivery, this goal of retaining existing customers and acquiring new customers is critically linked to service consistency (Herath et al, 2019). Surely, the failure of service organizations to maintain a level of service that the customer perceives to be excellent will generate dissatisfaction, this will adversely affect the reputation and prestige of the organization (Cox, 2016). Marketing literature always stresses the importance of producing and providing products with consistent and standard specifications in all circumstances. For services, providing homogeneous services is difficult (Baumann, 2019), it is commonly believed that services are inherently immaterial products and are less homogeneous than physical goods (Vargo \& Lusch, 2004). The difficulty of providing relatively consistent services is related to the human element or frontline employees in service organizations who interact with customers in service encounters, the attitudes, and behaviors of those employees determine the form and strength of the relationship with customers (Smith et al, 1999; Ashilla et al, 2008).

The problem of consistency in providing services appears more clearly in service organizations with labor-intensive (Wolak, 1998), when the level of performance of employees in the service encounter varies, up or perhaps down (Zeithaml, 1985). Although service providers encounter difficulties in achieving consistent results, a number of researchers go a point further and consider the inconsistency in service production to be a myth (Moeller, 2010). According to, Vargo and Lusch, (2004) the issue of inconsistency as an inherent characteristic of services that do not go beyond being a myth, and that similar outputs can be provided to multiple customers by focusing on the performance of the distinctive variable, which is the activity of service employees. At the same point, Levitt, (1981) argues that it is no longer appropriate to consider service production as inconsistent, many attempts have been made to develop the service production, whether by adopting technology or training and developing the capabilities of service staff to be at the level of skills that Achieve the good response for each customer. Likewise, Gummesson, (2007) indicated that banks can achieve consistency in their services by limiting the role of service staff in exchange for adopting technology to take more space in meeting customers' requirements, and a good example of this is the use of ATMs and credit cards that provide services normatively. Moreover, Cynthia, (2006) confirmed that service marketers should work intensively to overcome the problem of service inconsistency by listening well to the opinions and suggestions of customers and quickly addressing their complaints. Pulido et al, (2014) recommended 
that service organizations should be keen to provide superior services to customers on a continuum by establishing a system and work mechanisms based on rules and policies aimed at unifying the efforts of employees in their encounters with customers.

\section{B. Service Value}

It is known that the Perception embodies the imagination that arises in the minds of customers during the service encounter, as well as the way in which they interpret that imagination towards building a clearer picture of the attitude or behaviors you present the journey to obtain the service (Lekhanya \& Dlamini, 2017). According to Holbrook, (2006), value refers to "the customer's relative preferences resulting from his interactive experience of obtaining a service". While Zeithaml et al, (2006) defined value as "the evaluation that the customer gives with regard to the benefit achieved by a particular service". In a comprehensive sense, value means the psychological judgment of the customer that goes beyond the limits of financial sacrifice (Uddin \& Akhter, 2012). Although the term value is one of the cornerstones of customer satisfaction (Danish et al, 2018). Nevertheless, the value has received relatively limited attention in researches on service marketing, because of the assumption that the perceived value in the service is the same as in the good (Caruanaet al, 2000). With the expansion of global interest in services and the intensification of competition between service organizations, these organizations began to realize the importance of value in building and supporting competitive advantage (Hau \& Thuy, 2012). Frankly, the value represents the pivotal goal that the customer seeks to reach in every purchasing decision, and it is the critical dimension upon which building fruitful and successful business dealings with this customer (Lee et al, 2005).

\subsection{The Relationship Between Nonverbal Communication and Customer Perceptions}

The efforts of researchers and practitioners have documented the vital role of nonverbal communication in various areas of human life (McQuiston \& Morris, 2009; Najarzadegan \& Dabaghi, 2014). Besides, the impact of this form of communication is evident in the field of marketing, specifically in the aspect of service performance, Due to the nature of service provision that is completely different from the commodity, The success of producing and delivering services requires interactions and building in-depth relationships with customers, as frontline employees mainly contribute to building customer evaluations of the service they have received (Simat et al, 2018). The nonverbal behaviors and signals issued by the service staff have a clear relationship to creating an experience that the customer can see as distinctive or vice versa $(\mathrm{Wu}, 2018: 3)$, this means that nonverbal communication is the critical variable in determining the nature of customers' perceptions (Aqmala \& Ardyan, 2019). Thus, it is essential that frontline employees realize the importance of nonverbal or silent communication, and be professionally trained to master the behaviors involved in this communication to employ them in addressing customers (Bujalkova \& Zrinikova, 2016). In other words, service personnel must possess communication skills that enhance their ability to clearly 
exchange messages with customers to be qualified to respond to that customer's requirements (McPheat, 2012)

The results of studies (Mijung \& Younji, 2010; Yeon \& Ryong, 2011) revealed that the physical appearance of service employees, which includes hairstyle, dress, and elegance are important factors in communication and nonverbal cues, of course a service staff with physical attractiveness has a broader ability to persuade customers and influence their perceptions. Cavallone and Modina, (2013) point out that the service organization should consider the method of communication used as a tool that enhances relations with customers and a means of differentiation from competitors. Missaoui, (2015) emphasized that the form of communication used in interaction with the customer and in all aspects of marketing plays a major role in defining the perceived image of that customer towards salespeople or service staff and their organizations. According to, Sethi and Chandel (2015); Fifield (2015), the salesperson or service employee represents the face of the organization and the mediating link with customers, so it is necessary that frontline employees have an adequate understanding of nonverbal communication style so that they can employ these cues in service encounters. $\mathrm{Wu}$, (2018) added that the customer's perceptions are affected by what he perceives of verbal and nonverbal cues during his interaction with service employees, and that nonverbal behavior issued by service employees are silent messages that complement verbal communication and are necessary to enhance fruitful interactions with the customer. Based on the discussions and results highlighted by the above studies, the study hypotheses were developed as follows:

H1: Nonverbal communication has a positive influence on customer perceptions towards service encounters in Iraqi banks.

H2: Body Language in nonverbal communication has a positive influence on customer perceptions towards service encounters in Iraqi banks.

H3: Paralanguage in nonverbal communication has a positive influence on customer perceptions towards service encounters in Iraqi banks.

H4: Physical appearance in nonverbal communication has a positive influence on customer perceptions towards service encounters in Iraqi banks.

Figure 1 presents the conceptual model to be studied and the adopted hypotheses about the relationship between the independent variable represented by nonverbal communication in its three dimensions (1) body language, (2) paralanguage language, (3) physical appearance, and the dependent variable embodied by the customer's perceptions in two dimensions (1) service consistency and (2) service value. 


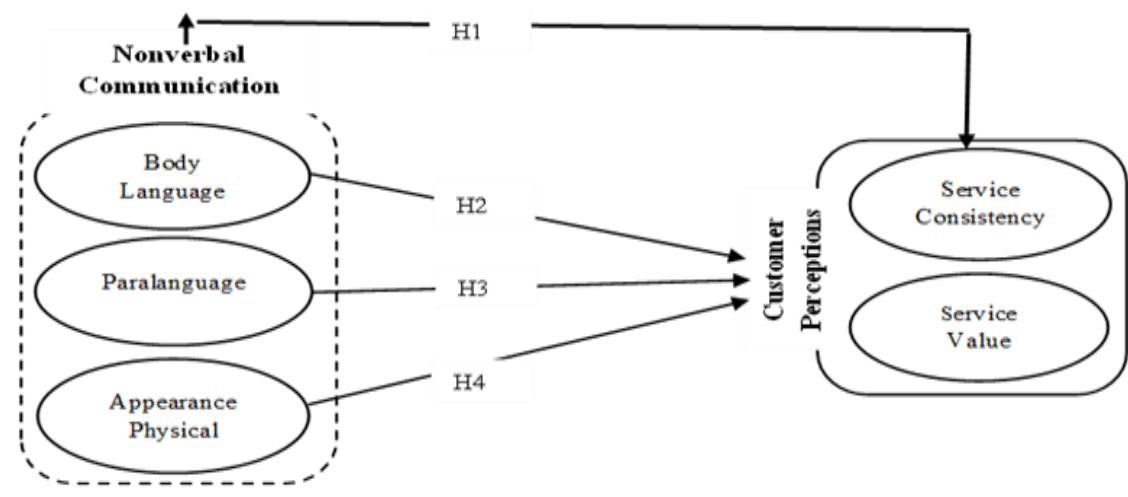

Fig. 1. The Conceptual Model

\section{Methodology}

\subsection{Study Design and Sample}

The quantitative research method was adopted to test the proposed study model. The study population was embodied by the banks operating in Basra Governorate - Iraq, the study sample was represented by customers who deal with these banks, and a sample of 397 respondents was surveyed using the random sampling method. Table 1. presents the demographic profile of the respondents. It is noted from the mentioned table that from this sample (281) were males and (116) were females (71 percent versus 29). The highest age group was within (41 to 50) years. Education Level "Bachelor's" achieved the highest percentage among the respondents, which amounted to (70\%). With regard to the service period from the bank, the period (4 to 6) achieved the highest percentage (42\%).

Table 1: Demographic Profile of the Respondents

\begin{tabular}{|c|c|c|c|}
\hline \multicolumn{2}{|l|}{ Variables } & \multirow{2}{*}{$\begin{array}{c}\text { Frequency } \\
281\end{array}$} & \multirow{2}{*}{$\begin{array}{c}\text { Percent } \\
71 \%\end{array}$} \\
\hline Gender & Male & & \\
\hline & Female & 116 & $29 \%$ \\
\hline \multirow[t]{4}{*}{ Age } & 20-30 Years & 92 & $23 \%$ \\
\hline & 31-40 Years & 112 & $28 \%$ \\
\hline & 41-50 Years & 137 & $35 \%$ \\
\hline & $50<$ Years & 56 & $14 \%$ \\
\hline \multirow[t]{5}{*}{ Education Level } & High School Certificate & 29 & $7 \%$ \\
\hline & Diploma & 41 & $10 \%$ \\
\hline & Bachelor's Degree & 277 & $70 \%$ \\
\hline & Master's Degree & 32 & $8 \%$ \\
\hline & Doctorate's Degree & 18 & $5 \%$ \\
\hline \multirow[t]{5}{*}{ Service period from the bank } & $>1$ Years & 112 & $28 \%$ \\
\hline & 1-3 Years & 167 & $42 \%$ \\
\hline & 7 Years -4 & 74 & $19 \%$ \\
\hline & 8-11 Years & 32 & $8 \%$ \\
\hline & $11<$ Years & 12 & $3 \%$ \\
\hline
\end{tabular}

n $=397$, Sources: Authors' survey. 


\subsection{Data Collection Instrument}

For the purpose of data collection, this study proceeded with the use of a two-part questionnaire, the first part included the personal information of the surveyed customers, while the second part covered the study variables (nonverbal communication, customer perceptions) with (16) questions as shown in Appendix 1.

The questionnaire in study was designed based on the scales used by the previous literature, and a number of modifications were made to its paragraphs to be compatible with the field targeted by the current study. The questions about the variable "Nonverbal communication behavior" were taken from (Lee, 2013; Lee \& Park, 2018). In contrast, the questions about variables of customer perceptions were taken from (Argan \& Argan, 2017). The questionnaire was distributed and collected in the field and over a period of time that took approximately two months.

\subsection{Data Analysis Methods}

In order to extract results and determine the validity of the hypotheses and test the conceptual model on which this study was built, the (SPSS) program was used to analyze the data and extract the results

\section{Results and Discussion}

\subsection{Reliability and Descriptive Analysis}

The first step in the process of analyzing the data collected from the field of study begins with the reliability test, and the Cornbrash's Alpha is often used as a necessary measure to diagnose and know the level of consistency between the answers of the study sample about the variables and items of the study tool. Statistical references indicate that the acceptable level in the test of reliability or consistency should not be less than a standard (0.70) (Nunnally, 1978). Table 2 illustrates the results of Cornbrash's Alpha test for the main and sub-variables of the study. It is clear that the nonverbal communication variable recorded a reliability coefficient (0.893), and the body language dimension achieved the highest value (0.934), while the lowest value was achieved in the dimension of the physical appearance (0.854). The customer perceptions variable achieved a reliability coefficient (0.831), the highest value recorded by the service value dimension was (0.857), Whilst the service consistency dimension recorded a reliability coefficient (0.805). In conclusion, it is inferred that the values extracted from the use of the Cornbrash's Alpha test in this study are acceptable and that the measures and items used have a high level of Reliability.

Within the contexts of statistical analysis procedures, mean and standard deviation measures were used in conducting descriptive statistics in order to determine the nature of the respondent's answers about the study items and variables. Table 2. shows the results of the descriptive statistical analysis. The achieved results showed that the answers were somewhat positive with the questions of the nonverbal communication variable, this was confirmed by $($ mean $=2.69$, standard deviation $=0.916)$. The body 
language dimension achieved the highest mean (2.89), the consistency in the answers was with an average dispersion confirmed by the standard deviation (.891). Whereas the physical appearance, the lowest mean was recorded (2.58), and there was a clear consistency in the answers confirmed by the standard deviation (.948). Similarly, the results of the descriptive statistic for the variable of customers' perceptions showed that it met with moderate approval through the mean (2.70), and the consistency in the answers was with an average dispersion confirmed by the standard deviation (.960).

Table 2: Results of Reliability Test \& Descriptive Statistics

\begin{tabular}{|l|c|c|c|c|}
\hline Variables & $\begin{array}{c}\text { Number of } \\
\text { Items }\end{array}$ & $\begin{array}{c}\text { Cornbrash's } \\
\text { Alpha }\end{array}$ & Mean & $\begin{array}{c}\text { Standard } \\
\text { Deviation }\end{array}$ \\
\hline $\begin{array}{l}\text { Independent Variable: } \\
\text { Nonverbal Communication } \\
\text { Behaviors }\end{array}$ & & 0.893 & 2.69 & .916 \\
\hline 1. Body Language & 4 & 0.934 & 2.89 & .891 \\
\hline 2. Paralanguage & 3 & 0.901 & 2.62 & .911 \\
\hline 3. Physical Appearance & 3 & 0.854 & 2.58 & .948 \\
\hline $\begin{array}{l}\text { Dependent Variable } \\
\text { Customer Perceptions }\end{array}$ & & 0.831 & 2.70 & .960 \\
\hline 1. Service Consistency & 3 & 0.857 & 2.73 & .951 \\
\hline 2. Service Value & 3 & 0.805 & 2.67 & .972 \\
\hline
\end{tabular}

Source: Survey Data.

\subsection{Correlation Analysis}

The second step in the statistical analysis process is to find out the Correlation between study variables, which is a measure of the strength and direction of the relationship between the studied variables (Schober et al, 2018). Table 3. presents the results regarding the correlation between the study variables according to Pearson coefficient, it is clear that there is a significant positive correlation between the nonverbal communication variable and customers' perceptions towards service encounters, and this was confirmed by the value of the correlation coefficient $\left(\mathrm{r}=.465^{* *}, \mathrm{p}<.01\right)$. As for the sub-dimensions, the moderately positive relationship achieved by the body language dimension with customers' perceptions $\left(\mathrm{r}=.367^{* *}, \mathrm{p}<.01\right)$. The paralanguage dimension within the verbal communication recorded a moderately positive relationship with customer perceptions $\left(\mathrm{r}=.299^{* *}, \mathrm{p}<.01\right)$. Whilst the dimension of physical appearance achieved a correlation coefficient $\left(\mathrm{r}=.174^{* *}, \mathrm{p}<.01\right)$, which reveals the weak positive relationship with the dependent variable in the study.

Table 3: Values of Person's Correlation Analysis

\begin{tabular}{|l|c|}
\hline Variables & Values \\
\hline Nonverbal Communication & $.465^{* *}$ \\
\hline Body Language & $367^{* *}$ \\
\hline Paralanguage & $.299^{* * *}$ \\
\hline Physical Appearance & $.174^{* *}$ \\
\hline
\end{tabular}




\subsection{Hypothesis Test}

The final step in the statistical analysis process is to test the study model and reveal the validity of the proposed hypotheses. Table 4 . presents the results extracted through linear and multiple regression analysis of the direction of the relationship between nonverbal communication as the expectation variable and customer perceptions that represented the response variable. The results of the mentioned table revealed the existence of a moderate influence relationship between the dimension of body language and the perceptions of customers confirmed by the influence coefficient $(\beta=0.397)$, and the calculated T (14.482) which is higher than the tabular T, the value $\left(R^{2}=0.19\right)$ which means that Body language explains (19\%) of the changes in customer perceptions variable, this supports H2. The Paralanguage dimension achieved a positive significant influence relationship with customers' perceptions through an influence coefficient that amounted to $(\beta=0.326)$, and the calculated $\mathrm{T}(11.422)$ which is higher than the tabular $\mathrm{T}$, the value $\left(\mathrm{R}^{2}=0.14\right)$, which means that the Paralanguage dimension was interpreted $(14 \%)$ of changes in customer perceptions, this supports H3. There was a weak influence relationship between the dimension of physical appearance of the service employees and the perceptions of customers, and this was confirmed by the influence coefficient $(\beta=$ $0.202)$, as well as the calculated T (8.161) which is higher than the tabular T, the value $\left(R^{2}\right.$ $=0.12)$ which means that the physical appearance It explains $(12 \%)$ of the changes in the response variable, this supports the acceptance of $\mathrm{H} 4$. As a result, it is noted from the same table that nonverbal communication positively affects customer perceptions, which was revealed by the influence coefficient $(\beta=0.559)$, the calculated $\mathrm{T}(3.323)$ is higher compared to the tabular $\mathrm{T}$, the nonverbal communication variable explained (37\%) from changes in customer perceptions, this supports $\mathrm{H} 1$.

Table 4: Results of Regression Analysis

\begin{tabular}{|l|c|c|c|c|}
\hline Independent Variables & $\boldsymbol{\beta}$ & $\mathbf{R}^{\mathbf{2}}$ & $\mathbf{T}$ & Hypothesis \\
\hline Nonverbal Communication & .559 & .37 & 16.518 & H1 - Accepted \\
\hline Body Language & .397 & .19 & 14.422 & H2 - Accepted \\
\hline Paralanguage & .326 & .14 & 11.947 & H3 - Accepted \\
\hline Physical Appearance & .203 & .07 & 8.161 & H4 - Accepted \\
\hline
\end{tabular}

Note: $\mathrm{p}<0.01$, $(\mathrm{T}$ tabulated $=3.323)$

\section{Conclusion and Recommendations}

The study sought to delve into one of the marketing variables that the previous literature has proven that its measurement is the entrance to develop and provide distinguished services is customer perceptions, and then highlighting the extent to which these perceptions are influenced by the nonverbal communication variable, which several studies in psychology have confirmed its role in promoting communication and understanding between humans. It is concluded in the current study, that there is limited awareness among the frontline employees in the banks under study regarding nonverbal communication and its importance as a complementary and enhanced form of the 
language of understanding with customers, this means that the use for such behaviors and cues by these employees did not go outside the framework of innately acquired practices. However, such practices and indications have been proven to positively affect the perceptions of the Surveyed customers. The results extracted in the field of statistical treatments confirmed the acceptance of the hypotheses about the obvious influence of facial expressions, eye gazes, gestures, tone of voice, and physical appearance of the frontline employees of the banks under study on the image that the customer perceives of the reality of production and service delivery. Although a number of previous studies revealed that the means and tools of nonverbal communication (body language, Paralanguage, physical appearance) are equally important in influencing the perceptions of customers, but the answers of the respondent customers showed that body language has an influence Stronger on their perception towards service encounters.

The study came out with a set of recommendations, foremost of which is the need for the concerned banks to be aware of the importance of the perceptions that the customer will draw in his imagination about the service encounter as an echo of the expectations and experience in the customer journey of obtaining the service. More precisely, the customers' perceptions are a major determinant of the shape and strength of the future relationship between the customer and the bank, and therefore there must be noticeable concerns from the bank's administrations to keep an eye on these perceptions on an ongoing basis. The Concerned banks should seek to build a friendly climate in the production and delivery of service in which a work culture focused on the principle of customer friendship prevails, where the verbal communication language used by service employees is integrated with nonverbal behaviors and signals to enhance understanding and rapprochement with customers, this will inevitably lead to the customer feeling more valued and respected and that there is an ear that listens well to his requirements. Although nonverbal communications and the associated behaviors and signals represent the capabilities that humans possess by instinct, it is necessary for the concerned banks to invest more efforts in enhancing their employees' awareness of the importance and role of such communications, which can convey messages and meaning more clearly than language or spoken words. Furthermore, it is necessary to involve frontline employees in training courses that boost their skills in using verbal and silent or nonverbal communication methods in service encounters, because such courses will improve the capabilities of these employees in good listening and rapid response to the customer. Not to mention the traditional methods of customer service must be abandoned by employing technology and electronic financial systems that enhance the value of the service

\section{Conflict of Interest Statement}

The author declares no conflicts of interests. 


\begin{abstract}
About the Author
Raafat Awad Mosa, MSc in Business Admin, Lecturer at Basrah University, College of Admin and Economics, Specialized in Marketing Management, author of several books and studies in Marketing Management.
\end{abstract}

\title{
References
}

Abdullah, Z., Ling, T., Sulaiman, N., Radzi, R. (2020). The Influences of Verbal Communication Behaviors on Communication. Journal of Critical Reviews, 7(12), 697-703.

Abercrombie, D. (1968). Paralanguage. British Journal of Disorders of Communication 3(1), 55-59.

Abushihab, I. M. (2012). A Semiotic-based Approach as an Influencive Tool for Teaching Verbal and Non-verbal Aspects of Language. Journal of Language Teaching and Research, 3(6), 1150-1156.

Allan \& Pease, B. (2004). The Definitive Book of Body Language. Harper Collins Publishers Australia, London-Orion.

Aqmala, D. \& Ardyan, E. (2019). How Does a Salesperson Improve Their Performance? The Important Role of Their Customer Smart Response Capability. Gadjah Mada International Journal of Business, Vol. 21, No. 2, pp.223-241.

Argan, M. \& Argan, M. (2017). Relationships Between Service Personal Values, Service Value, Satisfaction, and Loyalty: A Study Regarding Services of Private and State Hospitals in Turkey. International Journal of Medical Research \& Health Sciences, 6(6), 89-99.

Bailey, B. (2018). The Importance of Nonverbal Communication in Business and How Professors at the University of North Georgia Train Students on the Subject. Bachelor Thesis, University of North Georgia.

Barreto, A. (2017). Application of Facial Expression Studies on the Field of Marketing. The brain and the face, (9), 163-189.

Bicki, A. (2008). An Observation of Nonverbal Immediacy Behaviors of Native and Nonnative Lecturers. Çağ University Journal of Social Sciences, 5(1), 1-20.

Blahova, M. (2015). Specific Role of Nonverbal Communication in Business. European Scientific Journal, 11(10), 9-19.

Boamah, F., Asi Danso, N., Nutakor, J. (2020). Customer Perception and Satisfaction Towards Service Providers., Journal of Marketing and Consumer Research, (71), 30-37.

Bonaccio, S., Reilly, J., Sullivan, S., Chiocchio, F. (2016). Nonverbal Behavior and Communication in the Workplace: A Review and an Agenda for Research. Journal of Management, 2(1), 1-31. DOI: 10.1177/0149206315621146

Bose, A. (2019). Gender Differences and Power in Non-Verbal Communication. Bachelor thesis, State University of New York -Empire State College. 
Bujalkova, M. \& Zrnikova, P. (2016). Nonverbal Communication for the Enhancement of Foreign Language Professional Competency in Medical Students. Athens Journal of Philology, 3(3), 175-188.

Cavallone, M. \& Modina, M. (2013). Customer Perception of Bank Communication: Evidence and Implications. Corporate Ownership \& Control, 10(4), 299-307.

Chapman, G. (2018). Inside Sales vs. Outside Sales \& the Evolving Art of Communication. Master Thesis, University Honors Program.

Cho, Y. (2012). The Influences of Salesperson's Nonverbal Communication on Consumer Emotions and Service Quality in Fashion Shopping. Journal of the Korean Society of Clothing and Textiles, 14(3), 413-422.

Cox, N. (2016). Is a lack of consistency letting your customer service down? https://www.eptica.com/blog/lack-consistency-letting-your-customer-servicedown-0.

Cynthia, C. (2006). Four Factors that Distinguish Services Marketing. http://www.marketingprofs.com.

Danish, R., Humayon, A., Iqbal, H., Shoaib, S. (2018). The Impact of Service Quality and Service Value on Customer Satisfaction through Customer bonding Evidence from telecommunication Sector. European Online Journal of Natural and Social Sciences, 7(1), 40-47.

Denault, V., Plusquellec, P., Jupe, L., St-Yves, M., Dunbar, N. (2020). The analysis of nonverbal Communication: The dangers of pseudoscience in security and justice contexts. Anuario de Psicología Jurídica, 30, 1-12.

Fifield, C. (2015). Setting the Sale through Persuasive Communication. Keller Center Research Report, 8(3), 1-8.

$\mathrm{Fu}, \mathrm{Y}$. (2016). Exploring the Influence of Customer Behavior on Frontline Employee Engagement. Master thesis, University of Waterloo.

Gabbott, M. \& Hogg, G. (2000). An empirical investigation of the impact of non-verbal communication on service evaluation. European Journal of Marketing, 34(3/4), 384-398.

Gamble, T. \& Gamble, M. (2019). The Interpersonal Communication Playbook. SAGE Publications, Inc.

Hacioglu, N., Sahin, B., Sahin, S. (2008). The Influences of Body Language in Personal Selling in Tourism Industry. Management and Education, 4 (1), 219-229.

Hammed, S., Sabanayagam, A, Ramakalaivani, E. (2020). A Review on Facial Expression Recognition Systems. Journal of critical reviews, 7(4), 903-905.

Heide, F. J. (2013). Easy to sense but hard to define: charismatic nonverbal communication and the psychotherapist. Journal of Psychotherapy Integration, 23, 305-319.

Herath, A., Mallawaarachchi, H., Rathnayake, R. (2019). Service Consistency Improvement of Facilities Management Service Providing Organizations in Sri Lanka. $8^{\text {th }}$ World Construction Symposium, Colombo, Sri Lanka, ,513-523. https://www.researchgate.net/publication/337112205. 
Hoang, A. Q. (2011). Employees' Perception of the Role of Communication with Customers in Service Encounters Case studies at Bank Customer Services in Vietnam. Master of Communication Thesis, University of Gothenburg.

Holbrook, M. B. (2006). Consumption experience, customer value, and subjective personal introspection: An illustrative photographic essay. Journal of business research, 59(6), 714-725. doi: 10.1016/j.jbusres.2006.01.008.

Hoyer, W., MacInnis, D., Pieters, R. (2012). Consumer Behavior. $6^{\text {th }}$ ed, Southwestern, Cengage Learning.

Irabatti, P. (2012). Study on Increasing Importance of Nonverbal Communication in Retail Industry. Journal of Research in Commerce and Management 1 (4), 96-103.

Jung, H. \& Yoon, H. (2010). The Influences of Verbal and Nonverbal Communication of Service Providers in the Family Restaurant on the Customers' Trust and Satisfaction. Korean J. Food Cookery Sci, 26(3), 272-280.

Jung, L., Seok, Y., Yong, K. (2012). The Influence of Service Providers' Communication on Customer's Emotions and Satisfaction Focused on Ethnic Restaurants. Hotel Management Research, 21(6), 145-162.

Konya, M. \& Missouri, A. \& Ball, K. (2014). Customer Perception and Reality: Unraveling the Energy Customer Equation. http://support.sas.com/resources/papers/proceedings14/1686-2014.pdf.

Kyungae, K., Sanghee, K., Manseok, P., Jaebeom, P. (2011). Influence of Salesperson's and Customer's Nonverbal Communication at Service Encounter. Management Information Research, 3(4), 45-71.

Lake, L. (2009). Consumer Behavior for Dummies. Wiley Publishing, Inc., IndianapolisIndiana.

Lee, Y. \& Park, H. (2018). A Study on the Influence of Nonverbal Communication of Airline's Flight Crew on Customer Attitudes. Journal of Distribution Science, 16(7), 17-24.

Lee, Y., Park, K., Park, D., \& Lee, K., Kwon, Y. (2005). The Relative Impact of Service Quality on Service Value, Customer Satisfaction, and Customer Loyalty in Korean Family Restaurant Context. International Journal of Hospitality \& Tourism Administration, 6(1), 27-51. DOI:10.1300/J149v06n01_03.

Lim, E., Lee, Y., Foo, M. (2016). Frontline employees' nonverbal cues in service encounters: a double-edged sword. Journal of the Academy of Marketing Science, $45,657-676$.

Lower, J. (2018). Style Speaks: Clothing Judgments, Gender Stereotypes and Expectancy Violations of Professional Women. Master Thesis, M.A. University of Central Florida.

McPheat, S. (2012). Basic Selling Skills. MTD Training \& bookboon.com (Ventus Publishing ApS).

McQuiston, D. Morris, K. (2009). Gender Differences in Communication: Implications for Salespeople. Scholarship and Professional Work - Business. 45, 54-64. 
Mijung, K. \& Yoonji, B. (2010). A Study on the Impact of Nonverbal Communication on Customer Satisfaction and Word of Mouth Influence in the Beauty Service. Journal of Korean Skin Aesthetic Society, 8(4), 1-13.

Missaoui, Y. (2015). Non-verbal communication barriers when dealing with Saudi sellers. International Journal of Organizational Leadership 4, 392-402.

Mmutle, T. \& Shonhe, L. (2017). Customers' perception of Service Quality and its impact on reputation in the Hospitality Industry. African Journal of Hospitality, Tourism and Leisure, 6 (3), 1-25.

Mujezinovic, N. (2011). The importance of non-verbal communication in business. Bachelor Thesis, Tomas Bata University.

Najarzadegan, S. \& Dabaghi, A. (2014). Influencive Nonverbal Communications and English Language Classrooms. Iranian Journal of Research in English Language Teaching, 2(2), 109-118.

Negi, J. S. (2009). The role of teachers' Nonverbal communication in ELT classrooms. Journal of NELTA, 14(1-2), 101-110.

Nunnally, J. C. (1978). Psychometric Theory., New York- McGraw-Hill.

Pauser S. \& Wagner, U. (2019). A wearable sales assistant: capturing dynamic nonverbal communication behaviors using sensor technology. Marketing Letters 3013-25.

Piric, V., Martinovic, M., Barac, Z. (2018). A Study on Customer's Perception of Croatia's Banking Industry. UTMS Journal of Economics, 9 (2), 169-180.

Plumb, M.D. (2013). Non-Verbal Communication in Instant Messaging. Master Thesis, Southern Utah University.

Pulido, A., Stone, D., Strevel, S. (2014). The three Cs of customer satisfaction. https://www.mckinsey.com.

Samuels, P. \& Gilchrist, M. (2014). Pearson Correlation. Statistics teaching resources, Birmingham City University. https://www.researchgate.net/publication/274635640.

Sarpong, S. (2016). The Service Industry and the Moment of Truth. Athens Journal of Tourism, -3(1), 25-40. https://doi.org/10.30958/ajt.3-1-2.

Schober, P., Boer, C., Schwarte, L. (2018). Correlation Coefficients: Appropriate Use and Interpretation. Anesthesia \& Analgesia, 126(5), 1763-1768.

Sethi, A. \& Chandel, A. (2015). An Understanding of Salesperson Behavior and Characteristics: A Review of Literature. Asia Pacific Journal of Marketing \& Management Review, 4 (7), 6-17.

Sheahan, K. (2018). What Is Consistent \& Reliable Customer Service. https://careertrend.com/list-7769717-advantages-vs-outsourced-call-centers.html.

Simat, K., Blesic, I., Bozic, S. (2018). Customer orientation of employees in travel agencies as a predisposition of service quality. International Journal for Quality Research, 12(4), 851-868.

Tijana, T., Toporisic, T., Cuden, A. (2014). Clothes and Costumes as Form of Nonverbal Communication. Tekstilec, letn. 57(4), 321-333. 
Ulusoy E. (2015). The Impact of Variability of Front-Line Service Employees on the Customer Perceptions of Service Quality. In: Dato-on M. (eds) The Sustainable Global Marketplace. Developments in Marketing Science: Proceedings of the Academy of Marketing Science. Springer, Cham. https://doi.org/10.1007/978-3319-10873-5 251.

Wang, H. (2009). Nonverbal Communication and the Influence on Interpersonal Communication., Asian Social Science, 5(11) 155-159.

Webster, C. \& Sundaram, D. (2009). Influence of service provider's communication style on customer satisfaction in professional services setting: the moderating role of criticality and service nature. Journal of Services Marketing, 23(2), 103-113.

Weng, H. \& Chen, T. \& Lee, W. \& Ching-Sheng Chang, C. \& Lin, C. (2016). Internal Marketing and Its Moderating Influences between Service-Oriented Encounter and Patient Satisfaction. Acta Paul Enferm, 29(5):506-517. http://dx.doi.org/10.1590/1982-0194201600071.

Wu, S. (2018). I See What You Say: Influential Nonverbal Signals of Frontline Employees on Customer Outcomes. PhD Thesis, Louisiana Tech University.

Yeon, K. \& Ryong, H. (2011). The Influences of Verbal \& Non-Verbal Communication of Service Providers on Brand Image: Focused on Chain Restaurant. Hotel Management Research, 20(2), 69-88.

Zeithaml, V., Parasuraman, A., \& Berry, L. (1985). Problems and Strategies in Services Marketing., Journal of Marketing, 49, 33-46. http://www.jstor.org/stable/1251563.

Zin, N. T. (2019). Impact of Service Quality and Customer Perception: A Case Study of Private Clinics in Myanmar. Master thesis, Siam University, Bangkok- Thailand. 


\section{Appendix 1: Questionnaire Items}

\begin{tabular}{|c|c|c|}
\hline \multirow{2}{*}{\multicolumn{2}{|c|}{ Questions }} & \multirow{3}{*}{ 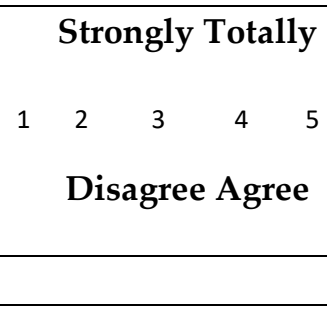 } \\
\hline & & \\
\hline & The Nonverbal Communication & \\
\hline & Body language & \\
\hline 1 & The facial expressions of the frontline employees are bright and warm. & \\
\hline 2 & $\begin{array}{l}\text { The bank's frontline employees meet customers' requirements with a } \\
\text { wide smile. }\end{array}$ & \\
\hline 3 & $\begin{array}{l}\text { The eye glances of the frontline employees in the bank often express } \\
\text { the familiarity and the principle of customer friendship. }\end{array}$ & \\
\hline \multirow[t]{2}{*}{4} & The bank's frontline employees use appropriate hand gestures. & \\
\hline & Paralanguage & \\
\hline 5 & $\begin{array}{l}\text { The bank's frontline employees speak in a warm and gentle tone of } \\
\text { voice. }\end{array}$ & \\
\hline 6 & $\begin{array}{l}\text { The bank's frontline employees speak at an appropriate speed of } \\
\text { speech. }\end{array}$ & \\
\hline \multirow[t]{2}{*}{7} & $\begin{array}{l}\text { The style of speech and pronunciation of the frontline employees is } \\
\text { clear and understandable }\end{array}$ & \\
\hline & Physical appearance & \\
\hline 8 & The frontline employees are attractive in appearance. & \\
\hline 9 & The frontline employees wear formal and elegant uniforms. & \\
\hline \multirow[t]{3}{*}{10} & The frontline employees maintain a neat and stylish hairstyle. & \\
\hline & Customer Perceptions & \\
\hline & Service Consistency & \\
\hline 11 & The bank consistently provides excellent services. & \\
\hline 12 & $\begin{array}{l}\text { The response of the frontline employees has always been at a } \\
\text { reasonable and acceptable level in all my dealings with the bank. }\end{array}$ & \\
\hline \multirow[t]{2}{*}{13} & $\begin{array}{l}\text { The response of the frontline employees is always at a reasonable } \\
\text { and acceptable level in providing the service. }\end{array}$ & \\
\hline & Service Value & \\
\hline 14 & The provided services by the bank live up to my expectations. & \\
\hline 15 & $\begin{array}{l}\text { I really enjoy the time I spend in the bank during the period of } \\
\text { receiving the service. }\end{array}$ & \\
\hline 16 & The bank gives me a positive experience when receiving the service. & \\
\hline
\end{tabular}


Creative Commons licensing terms

Authors will retain copyright to their published articles agreeing that a Creative Commons Attribution 4.0 International License (CC BY 4.0) terms will be applied to their work. Under the terms of this license, no permission is required from the author(s) or publisher for members of the community to copy, distribute, transmit or adapt the article content, providing a proper, prominent and unambiguous attribution to the authors in a manner that makes clear that the materials are being reused under permission of a Creative Commons License. Views, opinions and conclusions expressed in this research article are views, opinions and conclusions of the author(s).Open Access Publishing Group and European Journal of Management and Marketing Studies shall not be responsible or answerable for any loss, damage or liability caused in relation to/arising out of conflict of interests, copyright violations and inappropriate or inaccurate use of any kind content related or integrated on the research work. All the published works are meeting the Open Access Publishing requirements and can be freely accessed, shared, modified, distributed and used in educational, commercial and non-commercial purposes under a Creative Commons Attribution 4.0 International License (CC BY 4.0). 